\title{
Kajian Meteorologi dan Oseanografi Perairan Balikpapan-Tarakan sebagai Rute Health Boat untuk Pelayanan Kesehatan Pulau Terpencil Kalimantan
}

\author{
Luh Putri Adnyani
}

Teknik Perkapalan, Institut Teknologi Kalimantan, Balikpapan. Email: luhputria@itk.ac.id

\begin{abstract}
Distribution of medical facilities in Indonesia is uneven, so residents in remote islands have difficulties to reach it. We need to build health boat, a floating facility that provide standard services like in the hospital, especially in Derawan and Tarakan Islands in East Kalimantan. This Health boat has a homebase in Balikpapan. Therefore, the condition of the sea between Balikpapan, Derawan, and Tarakan need to be reviewed. One method to determine the condition of the sea is analysis of meteorological and oceanographic, which enable us to get the maximum wave height estimation. Long tern wave forecast can be obtained by using statistical methods of measurement to provide data of high wave in $1,10,25,50$ and 100 years.
\end{abstract}

Keywords: Health Boat, Meteorology, Oceanografy, Wave Forecasting

\begin{abstract}
Abstrak
Persebaran fasilitas medis di Indonesia tidak merata, sehingga warga di pelosok dan kepulauan sulit menjangkaunya. Perlu dibangun health boat, fasilitas terapung yang menyediakan layanan standar rumah sakit. Terutama yang beroperasi di wilayah Kepulauan Derawan dan Tarakan di Kalimantan. Health Boat ini memiliki homebase di Balikpapan, sehingga kondisi perairan dari Balikpapan sampai ke Derawan dan Tarakan perlu ditinjau. Salah satu metode untuk mengetahui kondisi perairan adalah analisa meteorology dan oceanografi sehingga mendapatkan perkiraan tinggi gelombang maksimal. Ramalan gelombang jangka waktu panjang dapat diperoleh dengan metode statistik dari data pengukuran yang tersedia dan mendapatkan tinggi gelombang 1, 10, 25, 50 dan 100 tahun.
\end{abstract}

Kata Kunci: Health Boat, Meteorologi, Oseanografi, Peramalan Gelombang

\section{Pendahuluan}

Indonesia adalah negara kepulauan, terbentang dari Sabang di Aceh sampai Merauke di Papua, yang terbentuk dari ribuan pulau besar dan kecil, yang terhubung oleh berbagai selat dan laut. Dari sekian banyaknya pulau-pulau di Indonesia, yang berpenghuni hanya sekitar 6.000 pulau. Definisi pulau kecil berdasarkan UU no 27 tahun 2007, tentang Pengelolaan wilayah Pesisir dan Pulau-pulau Kecil, pulau kecil adalah pulau dengan luas lebih kecil atau sama dengan $2.000 \mathrm{~km} 2$ (dua kilo meter persegi) beserta kesatuan ekosistemnya. Merujuk hasil perhitungan luasan pulau di seluruh dunia, (Island Directory UNEP, 2006) diketahui bahwa pulau yang memiliki luasan lebih besar dari $2000 \mathrm{~km} 2$ sebanyak 28 pulau sehingga jika jumlah pulau Indonesia (berdasarkand data Depdagri) 17.504, maka jumlah pulau kecil di Indonesia adalah sebanyak 17.475. Sangat banyak pulau-pulau kecil yang menjadi wilayah kerja Direktorat Pemberdayaan Pulau-pulau Kecil, ini merupakan tantangan yang sangat besar dalam melakukan pengelolaan pulau-pulau kecil (http://www.ppk-kp3k.dkp.go.id/)

Banyaknya pulau yang dimiliki oleh Indonesia tidak didukung oleh persebaran fasilitas medis yang merata. Dokter, tenaga medis dan rumah sakit besar hanya dijumpai di kota-kota besar sehingga warga di pelosok dan kepulauan sulit menjangkaunya. Perlu dibangun sebuah health boat, rumah sakit yang menyediakan layanan standar rumah sakit. Kapal ini dilengkapi dengan fasilitas ruang periksa, kamar bedah, kamar rontgen, laboratorium, ruang rawat pasien, ruang arsip, kamar dokter, kamar perawat, kamar karyawan, ruang diskusi, dapur, kamar mandi, serta ruang kemudi kapal. Dek atas untuk nahkoda dan relawan, dek tengah berisi ruangan steril untuk operasi, dek bawah untuk laboratorium. 
TPA Tanjung Belit adalah salah satu TPA yang beroperasi di kabupaten Rokan Hulu, Provinsi Riau. TPA ini melayani sampah padat yang berasal dari Kawasan Perkotaan Pasir Pangaraian yang merupakan pusat pemerintahan kabupaten Rokan Hulu. TPA ini baru beroperasi pada tahun 2012, sehingga jumlah timbunan sampah yang ada di TPA ini relatif masih sedikit. Pada awal tahun 2015, area yang terpakai hanya meliputi $20 \%$ dari total bangunan landfill yang ada. Berdasarkan kondisi tersebut, pendataan dan estimasi kandungan DOC untuk TPA ini menjadi penting sebagai bagian dari estimasi potensi metana $\left(\mathrm{CH}_{4}\right)$ yang menjadi dasar dalam pengelolaan dan pemanfaatan gas tersebut serta sebagai nbagian dari kegiatan inventarisasi GRK di Provinsi Riau.

Dalam mendesain sebuah Health Boat perlu ditentukan rute kapal, lokasi pelayaran, jumlah yang dibawa (payload) dimana dalam hal ini ada jumlah pasien yang akan ditangani, untuk menentukan ukuran utama kapal dan rencana umum kapal. Penentuan rute kapal dan lokasi pelayaran membutuhkan data lingkungan yang salah satunya adalah tinggi gelombang. Tinggi gelombang dilakukan dengan melakukan analisa gelombang. Analisa gelombang adalah analisa hindcasting untuk memprediksi gelombang ekstrim $(\mathrm{H1} / 3, \mathrm{~h} 1 / 10$, dan $\mathrm{h} 1 / 100)$ untuk periode perulangan 1 tahun, 10 tahun dan 100 tahun dengan menggunakan data angin dari satelit NOAA dan/atau sumber yang relevan lainnya. Analisa angin meliputi pembuatan wind rose diagram yang terkait untuk masing-masing lokasi.

Data lokasi yang diberikan meliputi daerah Balikpapan Balikpapan Kalimantan Timur dan data daerah Tarakan di dekat Pulau Mandul Kalimantan Utara. Beberapa lokasi untuk rute Health Boat tidak tersedia data gelombang dan data angin, sedangkan untuk mendapatkan data primer tinggi gelombang dan kecepatan serta arah angin di lokasi-lokasi tersebut maka perlu dilakukan pengukuran langsung gelombang maupun angin di sana, namun biaya survey sangat mahal. Oleh karena itu, digunakan data sekunder yang berasal dari data satelit terdekat. Data satelit yang tersedia adalah data pada titik-titik garis lintang dan bujur dengan selang $0.5^{\circ}$ atau selang 30 menit.

\section{Metode}

Hasil analisa jangka panjang gelombang dan angin berdasarkan data sekunder gelombang dan angin selama 4 tahun dari tahun 2005 sampai dengan tahun 2009 yang berasal dari data olahan satelit AVISO serta NOAA. Data yang dianalisa adalah data pada titik-titik yang ditentukan dan dianggap paling dekat dengan lokasi garis lintang dan bujur lokasi. Data didapat dari South East Asia Center for Ocean Researh and Monitoring (SEACORM) / Balai Riset dan Observasi Kelautan (BROK) Kementerian Kelautan dan Perikanan di Perancak Kecamatan Negara Kabupaten Jembrana Bali. Data juga dapat dilihat di http://www.aviso.oceanobs.com/es/data/products/sea-surface-height-products/index.html.

Gambar-gambar berikut adalah citra satelit yang diambil dari Google Earth. Gambar tersebut memperlihatkan jalur yang kemungkinan akan dilalui health Boat Titik-titik data satelit yang diambil adalah titik yang paling dekat dengan lokasi dimana untuk Balikpapan diambil Titik A $\left(01^{\circ} 30.000^{\prime} \mathrm{S}\right.$ dan $\left.117^{\circ} 00.000^{\prime} \mathrm{E}\right)$. Untuk lokasi Tarakan Kalimantan Utara diambil titik yang terdekat dengan lokasi tersebut yakni Titik K $\left(03^{\circ} 30.000^{\prime} \mathrm{N}\right.$ dan $\left.118^{\circ} 00.000^{\prime} \mathrm{E}\right)$. Titik-titik lokasi dari Titik B sampai dengan Titik J adalah titik-titik terdekat jalur pelayaran yang mungkin akan dilalui Health Boat dari Balikpapan ke Tarakan atau sebaliknya. Gambar 2 dan 3 adalah gambar perbesaran dari Gambar 1 masing-masing untuk lokasi Balikpapan dan Tarakan.

Khusus untuk desain Health Boat, karena jalur pelayarannya dari Titik A sampai dengan Titik K total sebanyak 11 titik-titik lokasi, maka data yang akan dianalisa adalah data 11 titik-titik lokasi tersebut dari Titik A sampai dengan Titik K. Dari 11 titik-titik lokasi tersebut dicari titik yang rata-rata gelombangnya tertinggi. 


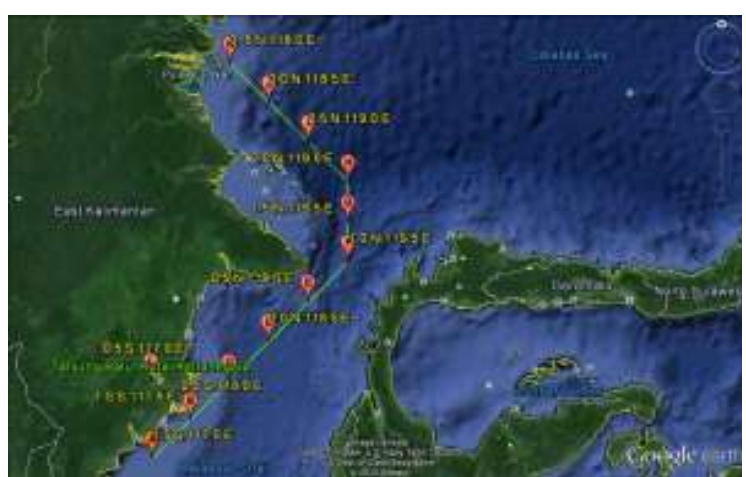

Gambar 1. Titik-titik jalur pelayaran dari Balikpapan ke Tarakan pulang pergi

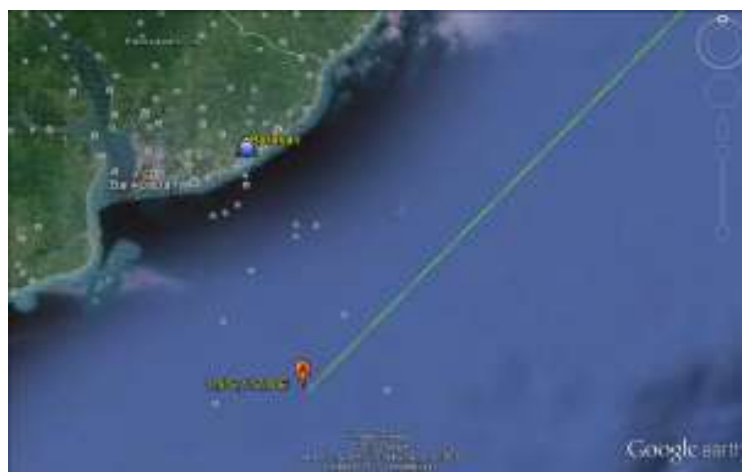

Gambar 2. Lokasi Balikpapan data, analisa gelombang dan angin diwakili data di Titik A

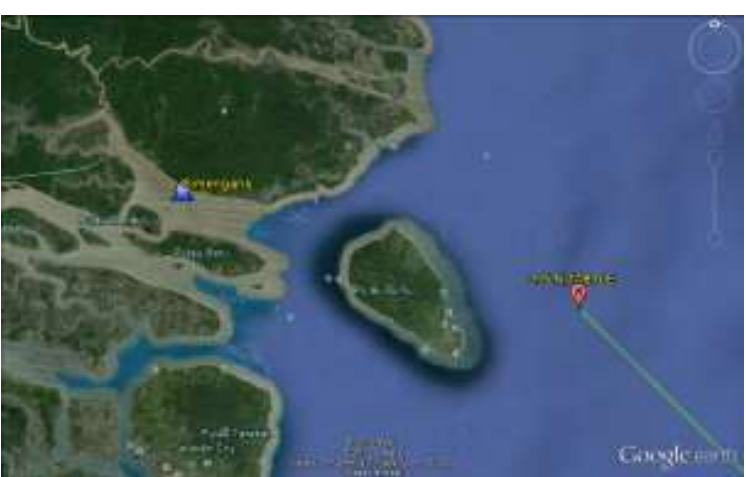

Gambar 3. Lokasi Tarakan, data analisa gelombang dan angin diwakili data di Titik K

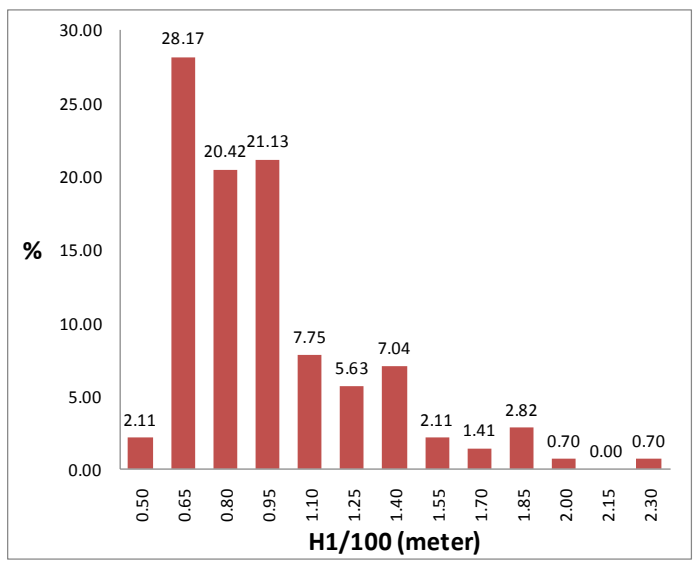

Gambar 4. Distribusi Probabilitas $\mathrm{H}_{1 / 100}$

Proses pengolahan data gelombang adalah sebagai berikut:

1. Pengumpulan data arah gelombang, tinggi gelombang, dan periode gelombang mulai Mei 2005 sampai dengan April 2009.

2. Diasumsikan distribusi kepadatan probabilitas tinggi gelombang dan periode gelombang mengikuti distribusi kepadatan probabilitas Weibull, sehingga perlu dicari parameter bentuk fungsi distribusi kepadatan probabilitas Weibull gelombang H1/3, H1/10, H1/100.

3. Dengan adanya parameter bentuk Weibull maka dapat digambarkan fungsi distribusi kepadatan probabilitas Weibull gelombang H1/3, H1/10, H1/100.

4. Dari distribusi kepadatan probabilitas Weibull ini dapat diprediksi dan diperkirakan tinggi gelombang H1/3, H1/10 , H1/100.dalam jangka waktu 1 tahun, 10 tahun, 25 tahun, 50 tahun, dan 100 tahun.

Proses pengolahan data angin adalah sebagai berikut:

1. Pengumpulan data kecepatan angin dan arah angin mulai Pebruari 2005 sampai dengan Agustus 2009.

2. Pengolahan data angin untuk mendapatkan diagram mawar angin (wind rose).

3. Untuk mendapatkan diagram mawar angin maka lingkaran mawar angin dibagi dalam 16 petak.

Fungsi distribusi Weibull diberikan dalam persamaan (1) berikut ini:

$$
P\left(H_{1 / 3} \leq h\right)=1-\exp \left(-\left(\frac{h-\gamma}{\beta}\right)^{m}\right)
$$

Notasi $P\left(H_{1 / 100} \leq h\right)$ berarti probabilitas bahwa $\mathrm{H}_{1 / 100}$ kurang atau sama dengan $h$. Kuantitas $m$ adalah parameter bentuk (shape parameter) yang harganya berkisar antara 0.75 sampai 2.0. Parameter $\beta$ dan $\gamma$ ditentukan dari pengamatan data dengan menggunakan metode least square. 
Bentuk alternatif fungsi distribusi Weibull yang sering digunakan (untuk $\gamma=0$ ) diberikan dalam bentuk persamaan (2) berikut ini:

$$
P(h)=1-\exp \left(-\left(\frac{h}{\beta}\right)^{m}\right) \beta, m>0
$$

Densitas probabilitas diperoleh dengan cara menurunkan persamaan (3) dengan variable $h$

$$
p(h)=\frac{m}{\beta}\left(\frac{h}{\beta}\right)^{m-1} \exp \left(-\left(\frac{h}{\beta}\right)^{m}\right)
$$

Jika persamaan (3) disusun kembali, maka persamaan (3) dapat ditulis dalam bentuk persamaan linear:

$$
\ln \left(\ln \frac{1}{1-p(h)}\right)=m \ln h+(-m \ln \beta)
$$

dimana $-m \ln \beta$ adalah titik perpotongan garis dengan sumbu $Y$ dan $m$ adalah gradient persamaan garis. Untuk satu set data, harga $\ln \left(\ln \frac{1}{1-p(h)}\right)$ dan $\ln h$ dapat dihitung.

Dari teori probabilitas, probabilitas kemunculan gelombang ekstrem dalam jangka waktu panjang adalah sama dengan menghitung probabilitas semua gelombang yang mempunyai tinggi gelombang kurang dari tinggi gelombang ekstrem. Hal ini dapat dihitung dengan mudah dengan cara mengurangkan probabilitas pasti terjadi(probabilitas $=1$ ) dengan pecahan lamanya waktu terjadinya badai (jam, menit, detik, dll) dengan periode kembali (return period) jangka panjang (10 tahun). Secara matematis hal ini dapat diekspresikan sebagai berikut:

$$
P_{10 \text { year }}(h)=P\left(h<H_{10 \text { year }}\right)=1-\frac{T_{\text {storm }}(\text { hour })}{T_{\text {year }} \times 365(\text { day }) \times 24(\text { hour })}
$$

\section{Hasil dan Pembahasan}

Pembahasan pada penelitian ini memuat tentang analisa gelombang di rute Health Boat yaitu dari Balikpapan Kalimantan Timur ke Tarakan di dekat Pulau Mandul Kalimantan Utara. Sehingga pembahasan dibedakan menjadi 3 titik yaitu lokasi dekat Balikpapan, lokasi dekat Tarakan dan rute pelayaran Balikpapan - Tarakan - Tanjung Batu yang diambil di titik H. Analisa yang dilakukan adalah perhitungan tinggi gelombang H1/100 1 tahunan, 10 tahunan dan 100 tahunan serta arah angin dominan dengan kecepatan angin dominannya.

\subsection{Analisis Keadaan Perairan di Balikpapan}

Data angin dan gelombang yang diambil di Titik A memuat nama file dengan informasi tanggal bulan dan tahun data diambil, longitude/posisi bujur (derajat), latitude/posisi lintang (derajat), wind direction (arah angin dalam derajat), $\mathrm{V}$ wind (kecepatan angin dalam knots), wave direction (arah gelombang dalam derajat) $\mathrm{H}_{1 / 3}$ atau significant wave height (rata-rata $1 / 3$ gelombang tertinggi dalam meter), $\mathrm{H}_{1 / 10}$ rata-rata $1 / 10$ gelombang tinggi yang tertinggi (dalam meter), $\mathrm{H}_{1 / 100}$ rata-rata gelombang tinggi yang tertinggi (dalam meter), $\mathrm{P}_{\text {average }}$ periode gelombang rata-rata (dalam detik), dan $\mathrm{P}_{\text {peak }}$ to peak periode gelombang rata-rata dari puncak gelombang ke puncak gelombang (dalam detik).

Dalam proses desain Health Boat, sebagai langkah awal diperlukan data gelombang hasil prediksi jangka waktu panjang sehingga desain dapat bertahan bila dalam jangka waktu panjang muncul gelombang dengan tinggi hasil interpolasi data gelombang yang sekarang. Dengan demikian analisa gelombang jangka waktu panjang tujuannya adalah untuk memprediksi dan merekonstruksi tinggi gelombang maksimum yang akan terjadi dalam 1 tahun, 10 tahun, 25 tahun, 50 tahun, atau 100 tahun mendatang. Proses rekonstruksi gelombang jangka waktu panjang memerlukan data-data frekuensi kemunculan gelombang signifikan $\mathrm{H}_{1 / 3}$ atau $\mathrm{H}_{\mathrm{s}}$ dan rata-rata periode gelombang dalam jangka waktu tertentu. Bagian penting dalam proses rekonstruksi ramalan gelombang jangka waktu panjang adalah pendefinisian kondisi gelombang yang akan direkonstruksi. Dalam banyak kasus kondisi gelombang 
pada saat terjadinya badai biasanya diambil sebagai patokan untuk prediksi kemungkinan gelombang ekstrim yang muncul dalam jangka panjang.

Kendatipun demikian tidak semua perairan mengalami kondisi ekstrim badai sehingga gelombang ekstrim saat badai tidak ada dalam rekaman gelombang dalam jangka waktu tertentu. Kondisi ini umum terjadi di perairan Indonesia. Tinggi gelombang lebih dari 3 meter hanya muncul 2 atau 3 kali dalam setahun di perairan tertentu. Mengingat hal tersebut sebagai ganti dari tiadanya data gelombang ekstrim maka gelombang signifikan $\mathrm{H}_{1 / 3}$ atau $\mathrm{H}_{\mathrm{s}}$ diganti dengan gelombang $\mathrm{H}_{1 / 100}$ dengan harapan gelombang tinggi untuk prediksi muncul dan akurasi prediksi dapat dipertanggungjawabkan.

Ramalan gelombang jangka waktu panjang dapat diperoleh dengan metode statistik dari data pengukuran yang tersedia (biasanya data rekaman gelombang minimum selama satu tahun). Dari analisa statistik data tersebut dilakukan ekstrapolasi untuk meramalkan besarnya gelombang dengan tinggi tertentu pada kondisi jangka waktu lama. Untuk perairan yang jarang mengalami kondisi ekstrim seperti perairan Selat Makassar sebelah barat, maka data periode gelombang yang digunakan untuk ramalan tinggi gelombang jangka panjang adalah periode gelombang paling dominan dalam rekaman data gelombang selama empat tahun dari Mei 2005 - April 2009.

\subsubsection{Analisa Statistik Gelombang $\mathrm{H}_{1 / 100}$}

Distribusi probabilitas tinggi gelombang $\mathrm{H}_{1 / 100}$ (dalam prosen) ditampilkan dalam Gambar 4. Bentuk distribusi ini adalah ciri khas distribusi gelombang dimana distribusinya lebih berat di sebelah kiri atau disebut Distribusi Rayleigh. Distribusi ini menunjukkan prosentase gelombang yang paling sering muncul adalah gelombang dengan tinggi antara $0.51-0.65 \mathrm{~m}$ dengan prosentase sebesar $28.17 \%$. Prosentase ini hampir sama dengan total prosentase tinggi gelombang di atas 1 meter yakni $28.16 \%$. Selama 4 tahun gelombang yang muncul di dekat Balikpapan hampir $72 \%$ tinggi gelombangnya di bawah 1 meter.

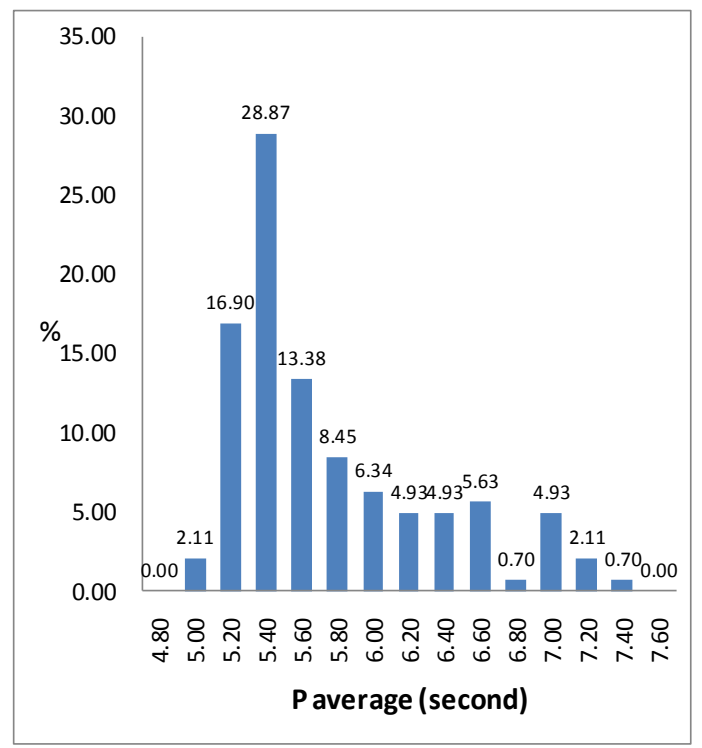

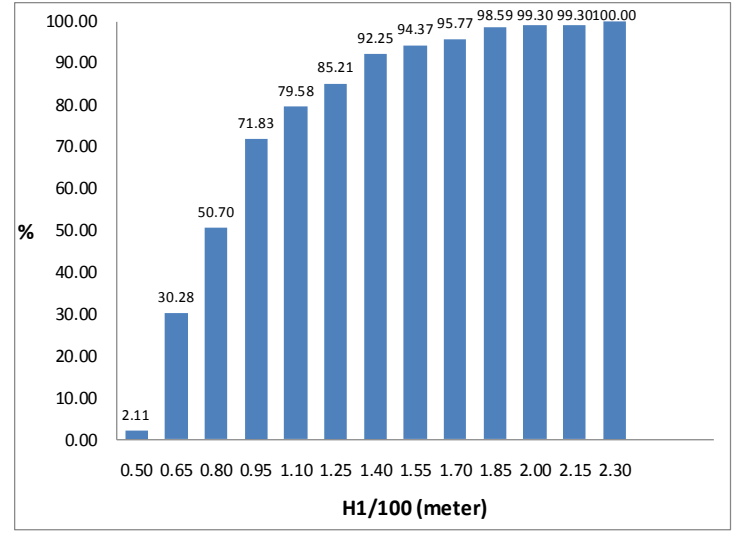

Gambar 6. Distribusi Kumulatif $\mathrm{H}_{1 / 100}$

Gambar 5. Distribusi Probabilitas Periode

Rata-rata

Gambar 5 menunjukkan distribusi probabilitas periode puncak gelombang H1/100. Distribusi ini mengikuti distribusi Gambar 4. Lancip tajam di sebelah kiri. Dari gambar ini dapat disimpulkan bahwa periode gelombang terbanyak yang muncul adalah periode gelombang rata-rata 5.40 detik. Gambar 6 menampilkan jumlah kumulatif tinggi gelombang H1/100. 


\subsubsection{Distribusi Gelombang H1/100 dalam Jangka Panjang}

Hal penting dalam analisa gelombang jangka panjang adalah memprediksi intensitas tinggi gelombang jangka panjang dari serangkaian pengukuran gelombang dalam jangka pendek. Jadi data untuk memprediksi jumlahnya terbatas. Dalam banyak kasus seperti dijelaskan dalam bab pendahuluan, kondisi gelombang yang akan diramal dihubungkan jumlah badai atau siklon tropis. Karena pada saat badai kemungkinan akan muncul gelombang tertinggi. Karena di daerah perairan sekitar Titik A di dekat perairan Balikpapan tidak ada hal istimewa berkenaan dengan badai atau siklon tropis maka digunakan periode gelombang yang paling banyak muncul seperti diperlihatkan pada Gambar 5 untuk prediksi tinggi gelombang jangka panjang, yakni periode gelombang 5.40 detik.

\subsubsection{Prediksi Tinggi Gelombang H1/100 10, 25, 50, dan 100 tahunan}

Dari teori probabilitas, probabilitas kemunculan gelombang ekstrem dalam jangka waktu panjang adalah sama dengan menghitung probabilitas semua gelombang yang mempunyai tinggi gelombang kurang dari tinggi gelombang ekstrem. Karena tidak ada data badai di perairan di Titik A dekat perairan Balikpapan, maka $T_{\text {storm }}$ diganti dengan periode gelombang yang paling banyak muncul seperti diperlihatkan pada Gambar 9. Dari Gambar 9 periode gelombang yang paling banyak muncul adalah periode average 5.40 detik. Jadi disini $T_{\text {storm }}=5.40$ detik. Tinggi gelombang $\mathrm{H}_{1 / 100}$ untuk periode kembali 10 tahunan dapat ditentukan dengan cara mensubstitusikan persamaan (2) ke persamaan (1). Tinggi gelombang prediksi 10 tahun dapat dihitung dari invers $\ln h_{10 \text { year }}$. Dari proses perhitungan di atas, dapat dihitung dan diprediksi gelombang 1 tahunan, 10 tahunan, 25 tahunan, 50 tahunan, dan 100 tahunan. Hasil prediksi gelombang jangka panjang adalah sebagai berikut:

Tabel 1. Prediksi Gelombang $\mathrm{H}_{1 / 100}$ Jangka Panjang 1, 10, 25, 50, 100 Tahunan Untuk Balikpapan

\begin{tabular}{|c|c|c|c|c|c|}
\hline & 1trhuman & 10tahmen & 25tahmon & 90 tahuman & 100tahran \\
\hline 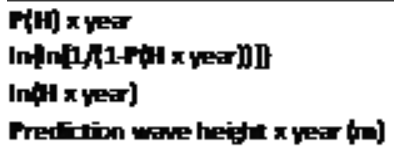 & 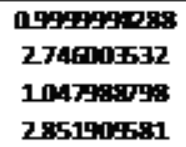 & 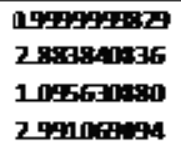 & 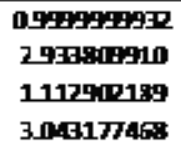 & 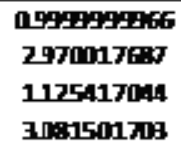 & $\begin{array}{l}0529299283 \\
304960144 \\
113749454 \\
311894421\end{array}$ \\
\hline
\end{tabular}

\subsubsection{Analisis Angin}

Dari data arah angin dan kecepatan angin untuk Titik A dekat Balikpapan, dapat dibuat diagram mawar angin (wind rose). Gambar 7 memperlihatkan mawar angin untuk Titik A. Terlihat dari gambar, angin dominan bertiup dari Selatan dan Selatan Barat Daya. Hal ini wajar karena Balikpapan terletak di belahan bumi selatan. Juga dari wind rose tersebut terlihat bahwa selama 4 tahun $25 \%$ arah angin bertiup dari arah Selatan Barat Daya dengan kecepatan dominan 5 - 7 knots. Disusul 13\% arah angin bertiup dari arah Selatan dengan kecepatan maksimal 13 knots.

Angin dengan kecepatan maksimal 13 knots bukanlah angin kencang yang dapat membahayakan bangunan di terminal atau pelabuhan Health Boat. Dalam skala kecepatan angin laut Beaufort (Beaufort scale), kecepatan 13 knots masuk kategori Beaufort 4, moderate Breeze (angin sepoi-sepoi yang menggerakkan dahan pohon). Namun demikian kemunculan angin dengan kecepatan 13 knots ini sangat kecil, hanya 2.1\%. Gambar di bawah ini menunjukkan skala Beaufort kecepatan angin.

\subsection{Analisa Gelombang di Perairan Dekat Tarakan}

Lokasi di Tarakan menggunakan lokasi data satelit yang terdekat dengan Tarakan adalah lokasi Titik K seperti diperlihatkan pada Gambar 3. Posisi Titik K adalah Lintang Utara $03^{\circ}$ 30.000'N dan Bujur Timur $118^{\circ} 00.000^{\prime} \mathrm{E}$. Dengan analisa yang sama seperti untuk peraian di Balikpapan, maka didapatkan hasil yang berbeda dengan data di Titik A dimana gelombang tinggi terjadi pada bulan Juli Agustus, untuk Titik K gelombang tinggi sekitar 1 meter lebih terjadi pada bulan Januari Pebruari saat musim angin dari barat bertiup.

\subsubsection{Analisa Statistik Gelombang $\mathrm{H}_{1 / 100}$}

Gambar 10 menunjukkan bahwa distribusi prosentase gelombang yang paling sering muncul adalah gelombang dengan tinggi antara $0.4-0.5 \mathrm{~m}$ dengan prosentase sebesar $14 \%$. Total tinggi gelombang antara 1 - 2 meter sebesar $38.02 \%$. Hal ini wajar karena laut di Titik K lebih terbuka menghadap ke Laut 
Sulawesi dibandingkan dengan laut dekat Balikpapan. Distribusi gelombang Gambar 10 adalah distribusi Rayleigh gemuk, lancip di kiri kemudian pelan-pelan melandai ke kanan. Gambar 11 menunjukkan distribusi probabilitas periode puncak gelombang $\mathrm{H}_{1 / 100}$. Distribusi ini mengikuti distribusi Gambar 10, melandai pelan-pelan ke sebelah kanan. Dari gambar ini dapat disimpulkan bahwa periode gelombang terbanyak yang muncul adalah periode gelombang rata-rata 5.35 detik. Gambar 16 menampilkan jumlah kumulatif tinggi gelombang $\mathrm{H}_{1 / 100}$.

\subsubsection{Prediksi Tinggi Gelombang $\mathrm{H}_{1 / 100}$ 10, 25, 50, dan 100 tahunan di Titik $\mathrm{K}$}

Besarnya prediksi tinggi gelombang jangka panjang 1 tahunan, 10 tahunan, 25 tahunan, 50 tahunan, dan 100 tahunan. Tabel 4, 5, dan 6 masing-masing menunjukkan hasil prediksi gelombang jangka panjang untuk $\mathrm{H}_{1 / 100}, \mathrm{H}_{1 / 3}, \mathrm{H}_{1 / 10}$.

Tabel 2. Prediksi Gelombang $\mathrm{H}_{1 / 100}$ Jangka Panjang 1, 10, 25, 50, 100 Tahunan Tarakan

\begin{tabular}{|c|c|c|c|c|c|}
\hline & 1trhman & 10tahumatin & Z5tahmen & Sotchuman & 100thaman \\
\hline 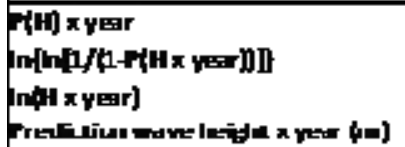 & 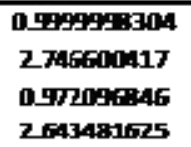 & 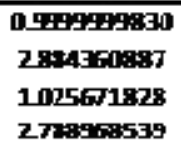 & $\begin{array}{c}0 \text { g99299997 } \\
2934304619 \\
104519493 \\
284368943\end{array}$ & 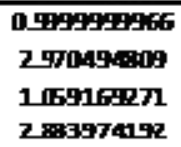 & 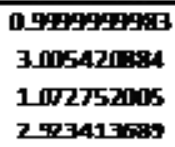 \\
\hline
\end{tabular}

Mengamati hasil prediksi jangka panjang di atas dapat disimpulkan bahwa prediksi gelombang jangka panjang di Titik K dekat dengan Tarakan relatif kecil.

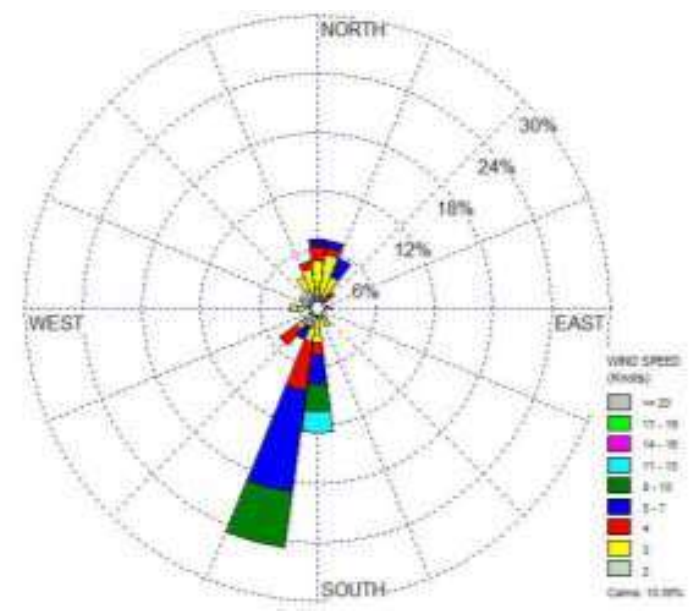

Gambar 7. Mawar angin untuk Titik A dekat Balikpapan

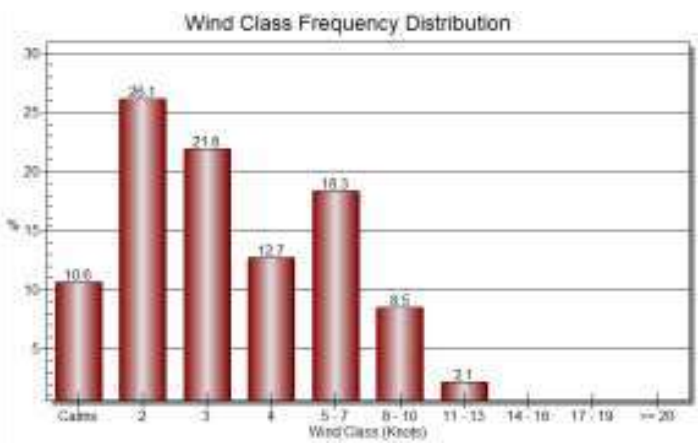

Gambar 8. Distribusi frekuensi kemunculan kecepatan angin di dekat Balikpapan

\subsubsection{Analisa Arah Angin dan Kecepatan Angin di Titik K Dekat Tarakan}

Hasil analisa arah angin dan kecepatan angin untuk Titik K dekat Tarakan dinyatakan dalam diagram mawar angin (wind rose) yang diperlihatkan di Gambar 13. Karena posisi Tarakan di belahan bumi utara maka angin selama 4 tahun dominan dari arah Timur Laut. Angin yang bertiup di sana rata-rata tipe angin sepoi-sepoi dengan kecepatan maksimal 10 knots. Kecepatan angin seperti ini tidak membahayakan keselamatan manusia maupun bangunan dan masuk dalam skala Beaufort 3 dengan prosentase sangat kecil 1.4\%. Gambar 14 menunjukkan prosentase distribusi frekuensi munculnya kecepatan angin. Dari data frekuensi tersebut kecepatan angin di daerah dekat Tarakan masuk kategori kecepatan rendah.

\subsection{Analisa Gelombang Untuk Jalur Pelayaran Antara Balikpapan dan Tarakan}

Sebagai dasar untuk desain Health Boat dengan rute Balikpapan dan Tarakan pulang pergi maka dilakukan analisa pendekatan rute jalur pelayaran yang mungkin akan dilalui oleh Health Boat yang disesuaikan dengan ketersediaan data satelit. Rute pelayaran telah ditunjukkan pada Gambar 1. Ada 11 titik yang mewakili rute jalur pelayaran. Titik-titik tersebut diidentifikasi dengan abjad mulai Titik A 
yang mewakili Balikpapan, Titik B, Titik C, dan seterusnya, dan berakhir di Tarakan yang diwakili oleh Titik K. Untuk mempercepat proses analisa maka tidak dilakukan analisa gelombang jangka panjang per titik rute, tetapi dengan cara menghitung rata-rata tinggi gelombang $\mathrm{H}_{1 / 3}, \mathrm{H}_{1 / 10}$, dan $\mathrm{H}_{1 / 100}$ selama 4 tahun untuk tiap titik rute. Rata-rata tinggi gelombang tiap titik dari Titik A ke Titik K tersebut kemudian dibandingkan satu sama lain. Rata-rata tertinggi akan dipilih sebagai acuan untuk prediksi tinggi gelombang jangka waktu panjang.

Rata-rata tinggi gelombang selama 4 tahun lebih dihitung dan rata-rata tertinggi dicapai oleh Titik H. Dengan demikian bahan acuan prediksi tinggi gelombang jangka panjang untuk data awal desain Health Boat dengan rute pelayaran dari Balikpapan ke Tarakan pulang pergi dipilih Titik $\mathrm{H}$ dengan posisi Lintang Utara $2^{0} 00.000^{\prime} \mathrm{N}$ dan Bujur Timur $119^{0} 30.000^{\prime} \mathrm{E}$.

\begin{tabular}{|c|c|c|c|c|c|c|c|c|c|c|}
\hline \multirow{2}{*}{$\begin{array}{l}\text { Beaufort } \\
\text { munber }\end{array}$} & \multicolumn{4}{|c|}{ Wind speed } & \multirow{2}{*}{$\begin{array}{r}\text { Mean wind } \\
\text { speed (ht/ } \\
\mathbf{k m h} / \mathbf{m p h})\end{array}$} & \multirow[b]{2}{*}{ Description } & \multicolumn{3}{|c|}{ Waveheiglt } & \multirow[b]{2}{*}{ Land conditions } \\
\hline & $\mathrm{kt}$ & $\mathrm{km} / \mathrm{h}$ & $\mathrm{mph}$ & $\mathrm{m} / \mathrm{s}$ & & & $m$ & $\mathrm{ft}$ & Sea conditions & \\
\hline 0 & 0 & 0 & 0 & $0-0.2$ & $0 / 0 / 0$ & Calm & 0 & 0 & Flat. & Calm. Smoke rises vertically. \\
\hline 1 & $1-3$ & $1-6$ & $1-3$ & $0.3-1.5$ & $02 / 04 / 2$ & Light air & 0.1 & 0.33 & Ripples without crests. & Wind motion visible in smoke. \\
\hline 2 & 46 & $7-11$ & 47 & $1.6-3.3$ & $05 / 09 / 6$ & $\underline{\text { Light }}$ & 0.2 & 0.66 & $\begin{array}{l}\text { Small mavelets. Crests of glassy } \\
\text { appearanoe, not breaking }\end{array}$ & $\begin{array}{l}\text { Wind felt on exposed skin. } \\
\text { Leaves ruste. }\end{array}$ \\
\hline 3 & $7-10$ & $12-19$ & $8-12$ & $3.4-5.4$ & $9 / 17 / 11$ & $\begin{array}{l}\text { Gentle } \\
\text { breeze }\end{array}$ & 0.6 & 2 & $\begin{array}{l}\text { Large wavelets. Crests begin to break; } \\
\text { scattered whitecaps }\end{array}$ & $\begin{array}{l}\text { Leaves and smaller twgss in } \\
\text { constant motion. }\end{array}$ \\
\hline 4 & $11-16$ & $20-29$ & $13-18$ & $5.5-7.9$ & $13 / 24 / 15$ & $\begin{array}{l}\text { Moderate } \\
\text { breeze }\end{array}$ & 1 & 3.3 & Small maves. & $\begin{array}{l}\text { Dust and loose paper raised. } \\
\text { Sinall branches begin to move. }\end{array}$ \\
\hline 5 & $17-21$ & $30-39$ & $19-24$ & $8.0-10.7$ & $19 / 35 / 22$ & $\begin{array}{l}\text { Fresh } \\
\text { breeze }\end{array}$ & 2 & 6.6 & $\begin{array}{l}\text { Moderae ( } 1.2 \mathrm{~m}) \text { longer waves. Some } \\
\text { foam and spray. }\end{array}$ & Sinaller trees smay. \\
\hline 6 & $22-27$ & $40-50$ & $25-31$ & $\begin{array}{l}10.8- \\
13.8\end{array}$ & $24 / 44 / 27$ & $\begin{array}{l}\text { Strong } \\
\text { breeze }\end{array}$ & 3 & 9.9 & $\begin{array}{l}\text { Large waves with foam crests and } \\
\text { some spray. }\end{array}$ & $\begin{array}{l}\text { Large branches in motion. } \\
\text { Whistling heard in overhead } \\
\text { wres. Umbrella use becomes } \\
\text { difficult. }\end{array}$ \\
\hline 7 & $28-33$ & $51-62$ & $32-38$ & $\begin{array}{l}13.9- \\
17.1\end{array}$ & $30 / 56 / 35$ & Near qale & 4 & 13.1 & $\begin{array}{l}\text { Sea heaps up and foam begins to } \\
\text { streak. }\end{array}$ & $\begin{array}{l}\text { Mhole trees in motion. Effort to } \\
\text { walk against the wind. }\end{array}$ \\
\hline 8 & 3440 & $63-75$ & $39-46$ & $\begin{array}{l}17.2- \\
20.7\end{array}$ & $37 / 68 / 42$ & Gale & 5.5 & 18 & $\begin{array}{l}\text { Modertely righ weves with breaking } \\
\text { crests foming spindritt. Streaks of } \\
\text { foam. }\end{array}$ & $\begin{array}{l}\text { Twigs broken from trees. Cars } \\
\text { veer on road. }\end{array}$ \\
\hline 9 & $41-47$ & $76-87$ & $47-54$ & $\begin{array}{l}20.8- \\
24.4\end{array}$ & $44 / 81 / 50$ & Strong gale & 7 & 23 & $\begin{array}{l}\text { High waves }(2.75 \mathrm{~m}) \text { with dense foam. } \\
\text { Wave crests sart to roll over. } \\
\text { Considerable spray. }\end{array}$ & Light strudure damage. \\
\hline 10 & $48-55$ & $\begin{array}{l}88- \\
102\end{array}$ & $55-63$ & $\begin{array}{l}24.5- \\
28.4\end{array}$ & $52 / 96 / 60$ & Storm & 9 & 29.5 & $\begin{array}{l}\text { Very tigh weves. The sea surface is } \\
\text { white and there is onnsiderable } \\
\text { tumbling. Wsibility is reduced. }\end{array}$ & $\begin{array}{l}\text { Trees uprooted. Considerable } \\
\text { structural damage. }\end{array}$ \\
\hline 11 & $56-63$ & $\begin{array}{l}103- \\
117\end{array}$ & 6472 & $\begin{array}{l}28.5- \\
32.6\end{array}$ & $60 / 111 / 69$ & $\begin{array}{l}\text { Volert } \\
\text { storm }\end{array}$ & 11.5 & 37.7 & Exceptionally righ waves. & \\
\hline 12 & $>63$ & $>117$ & $>72$ & $>32.7$ & N/A & Hurricane & $14+$ & $46+$ & $\begin{array}{l}\text { Huge waves. Ajr filled with foan and } \\
\text { spray. Sea completely white with } \\
\text { driving spray. Visibility very greatly } \\
\text { reduoed. }\end{array}$ & $\begin{array}{l}\text { Massive and widespread damage } \\
\text { to strudures. }\end{array}$ \\
\hline
\end{tabular}

Gambar 9 memperlihatkan frekuensi kemunculan kecepatan angin dalam prosen. Dari gambar tersebut terlihat kecepatan angin dominan di kecepatan 2 - 3 knots. Kecepatan angin yang cukup rendah dan tidak membahayakan bangunan di sekitar terminal LNG

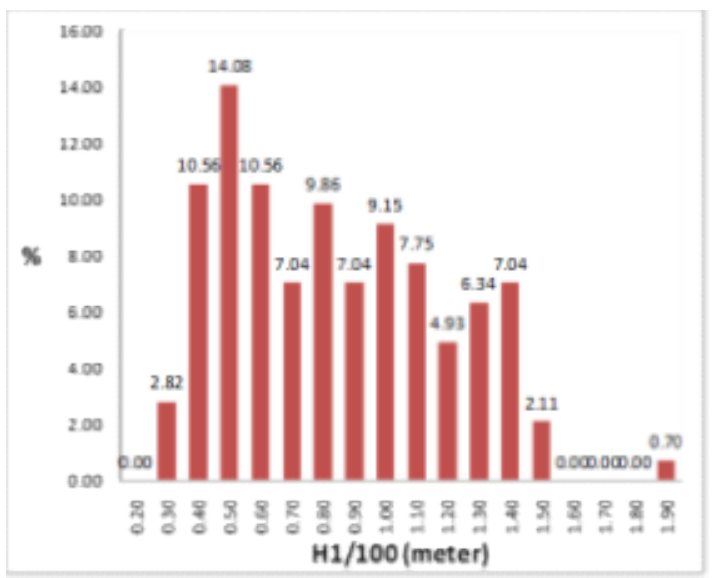

Gambar 10. Distribusi Probabilitas $\mathrm{H}_{1 / 100}$

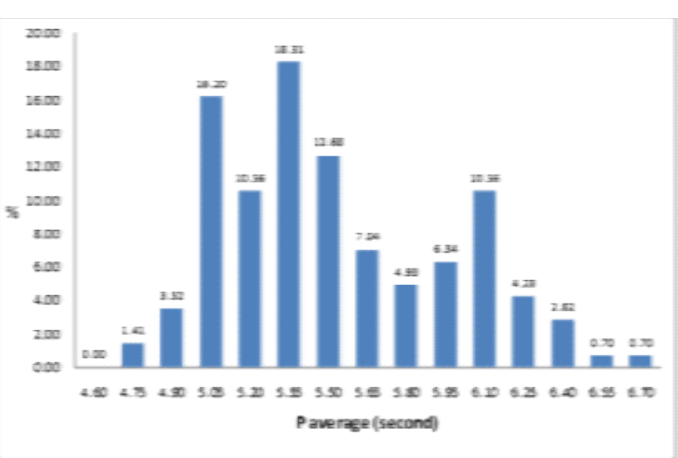

Gambar 11. Distribusi Probabilitas Periode rata-rata 


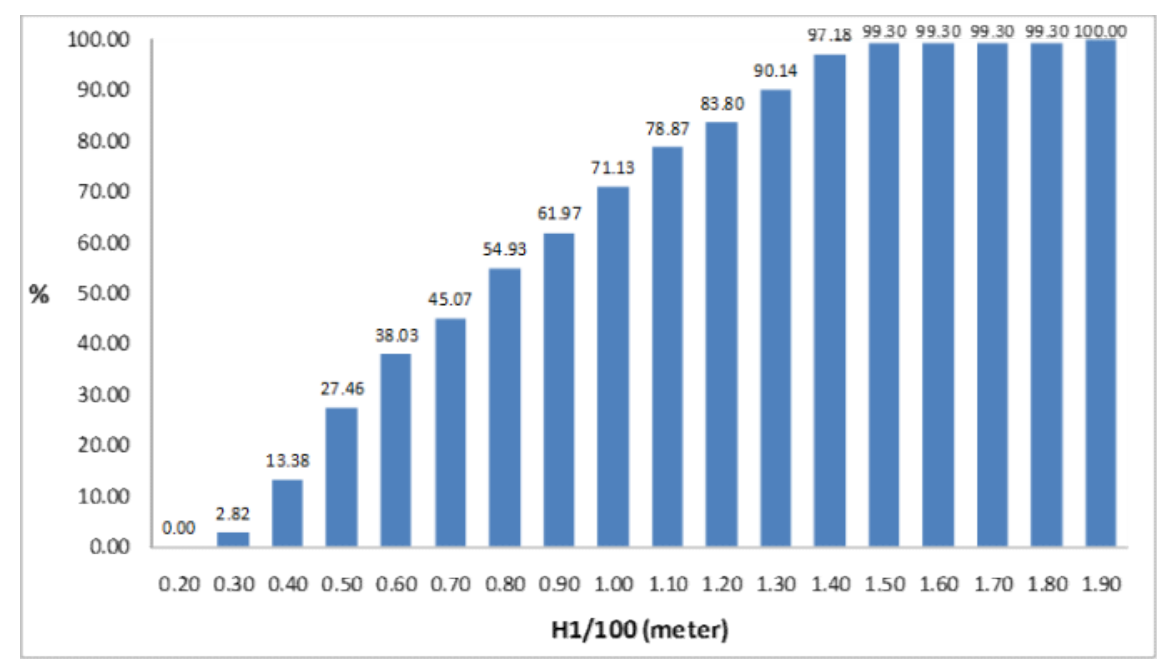

Gambar 12. Distribusi Kumulatif $\mathrm{H}_{1 / 100}$
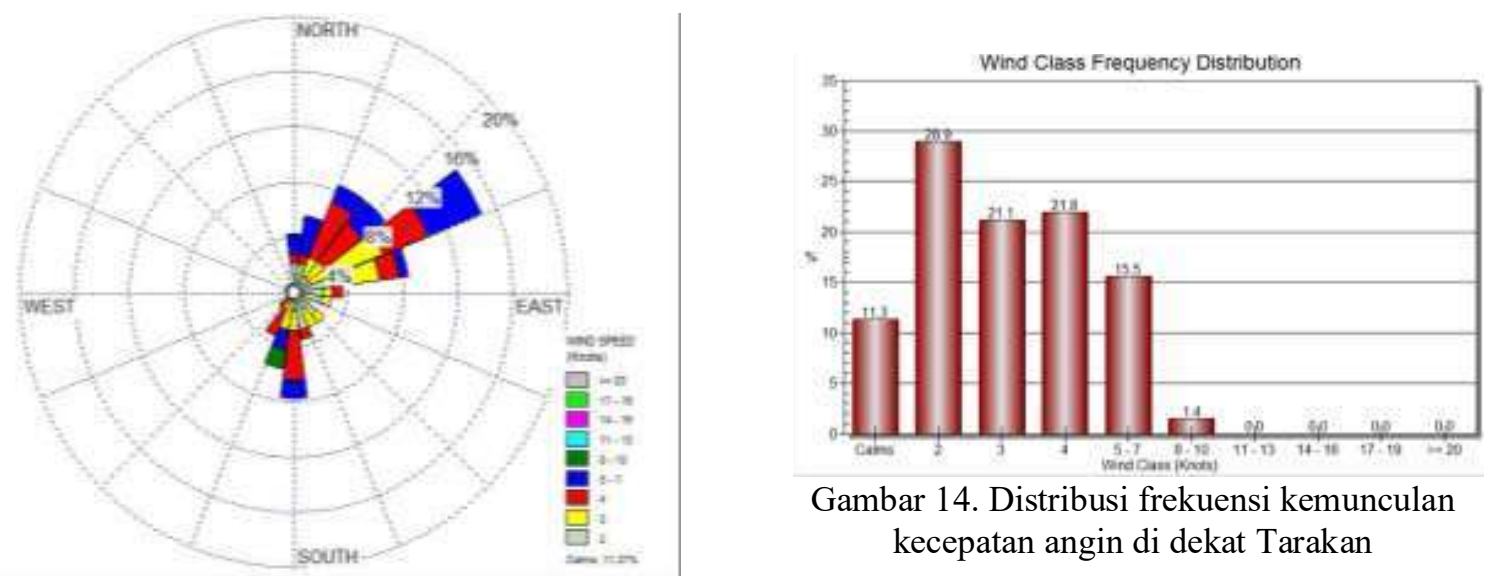

Gambar 14. Distribusi frekuensi kemunculan kecepatan angin di dekat Tarakan

Gambar 13. Mawar angin untuk titik K dekat

Tarakan

Distribusi probabilitas tinggi gelombang $\mathrm{H}_{1 / 100}$ (dalam prosen) di titik $\mathrm{H}$ menunjukkan prosentase gelombang yang dominan muncul adalah gelombang dengan tinggi antara 0.8 - $1.8 \mathrm{~m}$ dengan prosentase sebesar hampir 77\%. Distribusi gelombang Gambar 22 adalah distribusi Rayleigh gemuk, lancip di kiri kemudian pelan-pelan melandai ke kanan. Sehingga dapat disimpulkan bahwa periode gelombang terbanyak yang muncul adalah periode gelombang rata-rata 5.35 detik. Mengamati hasil prediksi jangka panjang di atas dapat disimpulkan bahwa prediksi gelombang jangka panjang di Titik $\mathrm{H}$ relatif cukup besar, terutama untuk prediksi $\mathrm{H}_{1 / 100}$ dimana prediksi jangka waktu 100 tahun mencapai 4.00 meter. Untuk desain Health Boat akan lebih baik dan aman menggunakan tinggi gelombang hasil prediksi jangka panjang dengan menggunakan $\mathrm{H}_{1 / 100}$ sebagai acuan dibandingkan dengan prediksi jangka panjang dengan menggunakan $\mathrm{H}_{1 / 3}$ atau $\mathrm{H}_{1 / 10}$.

\section{Kesimpulan}

Berdasarkan hasil diatas dapat disimpulkan sebagai berikut:

1. Untuk lokasi dekat Balikpapan

a. Prediksi gelombang jangka panjang

- Tinggi gelombang H1/100 1 tahunan adalah 2.85 meter

- Tinggi gelombang H1/100 10 tahunan adalah 2.99 meter

- Tinggi gelombang H1/100 100 tahunan adalah 3.12 meter 
b. Arah angin untuk lokasi dekat Balikpapan dominan dari Selatan Barat Daya dan Selatan dengan kecepatan angin dominan antara 2 - 7 knots. Maksimum kecepatan angin yang tercatat adalah 13 knots

2. Untuk lokasi Tarakan

a. Prediksi gelombang jangka panjang

- Tinggi gelombang H1/100 1 tahunan adalah 2.64 meter

- Tinggi gelombang H1/100 10 tahunan adalah 2.79 meter

- Tinggi gelombang H1/100 100 tahunan adalah 2.92 meter

b. Arah angin untuk lokasi dekat Tarakan dominan dari Timur Laut dengan kecepatan angin dominan antara 2 - 7 knots. Maksimum kecepatan angin yang tercatat adalah 10 knots

3. Untuk rute pelayaran Balikpapan - Tarakan - Tanjung Batu

Sebagai bahan design Health Boat, prediksi gelombang jangka panjang di titik $\mathrm{H}$, dengan nilai:

- Tinggi gelombang H1/100 1 tahunan adalah 3.65 meter

- Tinggi gelombang H1/100 10 tahunan adalah 3.83 meter

- Tinggi gelombang H1/100 100 tahunan adalah 4.00 meter

\section{References}

BMKG (Data Dan Informasi, 2015) : Data dan info meteorology Surabaya

CERC, 2006. Shore Protection Manual. Washington : US Army Coastal Engineering Research Center. 143 p.

Coastal Hydrolic Laboratory (CHL). 2006. Coastal Enginering Manual. Part III-IV. Washington DC : Department of the Army. U.S. Army Corp of Engineering.

Cruz, Joao., 2008. Ocean Wave Energy : Current Status and Future Perspectives. Springer-Verlag Berlin Heidelberg German. 427 pp.

Dijkstra, Henk A., 2008. Dynamical Oceanography. Springer-Verlag Berlin Heidelberg German. 405 pp.

Emery, William J. \& Thomson, Richard, E., 1998. Data Analysis Methods In Physical Oceanography. Pergamon Elsevier Science Ltd. p: $42-116$.

Herbich, John B. 2000. Handbook of Coastal Engineering. McGRAW-HILL Companies, Inc.

Holthuijsen, L. H. 2007. Waves In Oceanic And Coastal Waters. Cambridge University Press., Cambridge CB2 8RU, UK. 405p.

Triatmodjo B, 1999. Pelabuhan. Fakultas teknik Universitas Gajah Mada. Yogyakarta.

Tjasyono B H. K, 1999. Meteorologi Indonesia Vol 1, Karakteristik dan sirkulasi atmosfer.

Stewart, R.H. 2000. Introduction For Physical Oceanography.Departement Oceanography. Texan A M Univ.

Supangat, Susana 1994. Pengantar oseanografi

Sontek/YSI. 2009. The Argonaut-XR Expanded Description. SonTek/YSI . www.sontek.com diakses pada tanggal 11 Oktober 2009.

Soronsen, 2006. Basic Coatal Engineering. 3 rd edition. Department of Civil and Environmental Engineering Lehigh University, Bethlehem, Pennsylvania. 330p

Thurmann, Harold V., 2007. Introductory Oceanography. Bell and Howell Company Columbus Ohio. p: 183 -273 .

Triadmodjo, Bambang. 1999. Teknik Pantai. Beta Offset: Yogyakarta. Hal: $11-24$

Trujillo, Alan P. \& Thurman, Harold V., 2008. Essentials of Oceanography. Pearson Prentice Hall, Pearson Education Inc. New Jersey. 534 pp.

Wyrtki, Klaus. 1961. Physical Oceanography of the Southeast Asian Water. The University of California: California.

Young, Ian R. 1999. Wind Generated Ocean Waves. Elsevier Science Ltd. The Boulevard, Oxford OX 1GB, UK. $307 \mathrm{p}$.

Yuwono, Nur \& Kodoatie, R.J. 2004. Pengembangan Reklamasi Pantai dan Perencanaan bangunan Pengamannya (Pedoman). Direktorat Bina Teknik, Direktorat Jenderal Sumber Daya Air. 